\title{
Detection of Tilmicosin Residues by HPLC and its Effect on Cardiac Enzymes and Hematology in Broiler Chickens
}

\author{
Ahmed A. Said ${ }^{1}$, Sameh M. El-Nabtity ${ }^{1}$, Abdulla A.M. Selim², Mai A. Fadel ${ }^{2 *}$ \\ ${ }^{1}$ Pharmacology Department, Faculty of Veterinary Medicine, Zagazig University, 44511, \\ Egypt \\ ${ }^{2}$ Animal Health Research Institute, Dokki, Giza, Egypt
}

\begin{abstract}
Article History: Received: 29/2/2016 Received in revised form: 20/3/2016 Accepted: 15/6/2016
\section{Abstract}

The aim of the present study was to detect the tilmicosin residues in muscles, kidneys and liver of broiler chickens and to investigate its impact on both cardiac enzymes and some hematological parameters. Seventy broiler chickens were divided into two groups; the first was left as a negative control. The second group was given tilmicosin orally $(30 \mathrm{mg} / \mathrm{kg} \mathrm{BW})$ once/day for three successive days. Reversed phase-high performance liquid chromatography (RP-HPLC) with UV detector at $287 \mathrm{~nm}$ and solid phase extraction were used for detecting drug residues in tissue samples. Results indicated a widespread distribution of tilmicosin in most tested tissues. All tissue samples were considered tilmicosin free at the $9^{\text {th }}$ day after the last oral dose except liver. Tilmicosin elicited a significant reduction in red blood cells count, hemoglobin concentration, packed cell volume, lymphocytes and eosinophiles. On the other hand, heterophiles count and the mean corpuscular volume were increased significantly. White blood cells, monocytes, mean corpuscular hemoglobin and mean corpuscular hemoglobin concentration showed non-significant changes. Levels of all cardiac enzymes (Aspartate aminotransferase, lactate dehydrogenase, creatine kinase-MB and Troponin I) were high.

Keywords: Tilmicosin Residues, Hematological Parameters, Cardiac Enzymes, Broiler, HPLC

\section{Introduction}

Tilmicosin is a broad-spectrum bacteriostatic macrolide antibiotic synthesized from tylosin for veterinary use only. It is predominantly effective against Mycoplasma spp., Pasteurella spp. and various Grampositive organisms [1,2]. Tilmicosin is advised to be the drug of choice in respiratory infections specially in M. gallisepticum, Ornithobacterium rhinotracheale and $P$. multocida in broiler chickens $[3,4]$.

Tilmicosin caused cardiovascular toxicity and deaths by an intravenous administration or at doses much greater than therapeutic dose [57]. Its mode of action is through inhibition of protein synthesis by binding to the $50 \mathrm{~S}$ ribosomal subunit of sensitive microorganisms [8]. According to the European Medicines Agency and the veterinary drug residue regulations of the Chinese Ministry of Agriculture, the maximum residue levels (MRLs) of tilmicosin in broiler chicken muscles, kidneys and liver were $0.075,0.25$ and $1.0 \mu \mathrm{g} / \mathrm{g}$, respectively $[9,10]$. Abu-Basha et al. [4] mentioned that intravenous injection of tilmicosin $(15 \mathrm{mg} / \mathrm{kg} \mathrm{BW})$ in chickens caused a very serious cardiovascular effects (cardiac toxicity and necrosis of the cardiac muscle) and death.

Consumers eat tissues (milk, meat and eggs) which have antibiotic residues for a long time that can produce bacterial resistance and therapeutic failures among them. Similarly, administration of very low doses of some drugs for a prolonged time produce reproductive and teratogenic effects [11]. Not only the macrolides residues in edible products have direct toxic effects but also may lead to allergic reactions and development of resistant bacteria in humans [12].

The aim of this study was to investigate the residues of tilmicosin in broilers' tissues and its 
side effects on cardiac enzymes and hematological parameters.

\section{Material and Methods}

\section{Experimental animals and design}

Seventy healthy Hubbard broiler chickens, 4 weeks of age and 1150-1200 g weight were used. Chickens were obtained from a private poultry farm in Cairo. They were divided equally into two groups and housed in batteries (160 cm length, $140 \mathrm{~cm}$ width and $50 \mathrm{~cm}$ depth) at the graduate research laboratory, Animal Health Research Institute, Dokki. The first group was kept as a negative control and used for preparation of blank and spiked samples for validating the method. The second group was given tilmicosin phosphate (250 $\mathrm{mg} / \mathrm{mL}$, Advotil AC, CHEMVET, Advanced Agrochemicals and Veterinary Products Industrial Co, Amman, Jordan) directly into the crop in a dose of $30 \mathrm{mg} / \mathrm{kg}$ BW once/day for three consecutive days. Five chickens were sacrificed at $1^{\text {st }}, 3^{\text {rd }}, 5^{\text {th }}, 7^{\text {th }}, 9^{\text {th }}$ and $14^{\text {th }}$ day following the last oral dose. Samples from liver, muscles and kidneys were taken for quantitative determination of tilmicosin residues. Two blood samples were collected; the first $2 \mathrm{~mL}$ were collected with EDTA from the wing vein at $1^{\text {st }}, 3^{\text {rd }}, 5^{\text {th }}$ and $7^{\text {th }}$ day following the last oral dose for hematological examination. While, the second one $(3 \mathrm{~mL})$ was obtained at $1^{\text {st }}, 3^{\text {rd }}$ and $5^{\text {th }}$ day following the last oral dose to estimate the cardiac enzymes in the serum (Creatine kinase-MB, Lactate dehydrogenase, Aspartate aminotransferase and Troponin I).

\section{Analytical procedures}

\section{Preparation of samples for analysis}

At the time of assay, frozen chicken tissue samples were partially thawed at room temperature $\left(23^{\circ} \mathrm{C}\right)$ for $30 \mathrm{~min}$ and were minced and homogenized in the mincer for $1 \mathrm{~min}$.

\section{Drug residues extraction}

Extraction of the drug residues from the samples was carried out according to Zhang et al. [13]. Ten $\mathrm{mL}$ of acetonitrile were added to $5 \mathrm{gm}$ of the homogenized sample in a centrifuge tube $(50 \mathrm{~mL})$, then shaking for 20 min and centrifugation for $10 \mathrm{~min}$ at $3500 \mathrm{rpm}$ were carried out. The supernatant was transferred into a $50 \mathrm{~mL}$ polypropylene centrifuge tube. Five milliliters of monobasic potassium phosphate buffer and $8 \mathrm{~mL}$ of acetonitrile were added to the tissue pellet and thorough shaking of the mixture for $20 \mathrm{~min}$ was carried out. Centrifugation for $10 \mathrm{~min}$ at 3500 rpm was then performed. Supernatants were combined with $40 \mathrm{~mL}$ of HPLC water. The mixture solution was centrifuged at $3500 \mathrm{rpm}$ for $10 \mathrm{~min}$. The supernatant was introduced to solid phase extraction (SPE) cleanup step. The SPE was conditioned with $10 \mathrm{~mL}$ of methanol then $10 \mathrm{~mL}$ of deionized water and the sample was applied to the cartridge. The flow rate was not more than 2 drops/s. The cartridge was not allowed to dry at this step, so the cartridge was flushed with $10 \mathrm{~mL}$ water then $10 \mathrm{~mL}$ of acetonitrile was applied. The SPE cartridge was dried for at least 3 min under vacuum. Elution was performed successively with $2.5 \mathrm{~mL}$ Ammonium acetate $(0.1 \mathrm{~mol} / \mathrm{L})$ /methanol/ acetonitrile solution. The eluated solution was evaporated until dryness by a nitrogen stream at $30^{\circ} \mathrm{C}$ in a water bath. The sample was reconstituted by $1 \mathrm{~mL}$ dipotassium hydrogen phosphate buffer, mixed and filtered through $0.45 \mu \mathrm{m}$ filters before injection into HPLC.

Liquid chromatography operating conditions was adjusted for $100 \mu \mathrm{L}$ injected volume, flow rate, $0.7 \mathrm{~mL} / \mathrm{min}$; wave length, $287 \mathrm{~nm}$; column temperature, ambient; stop time: $30 \mathrm{~min}$; post time: $6 \mathrm{~min}$. The mobile phase A was $0.05 \%$ trifluoroacetic acid while mobile phase B was acetonitrile (gradient conditions) as at 0 minute $71 \%$ from mobile phase A and 29\% from B and at $11 \mathrm{~min} ; 54.5 \%$ from A and $45.5 \%$ from B. Finally; $50 \%$ was taken from mobile phase $A$ and the same from $\mathrm{B}$ at 11.5 and 14 minutes.

\section{Quantification}

Quantification of residues in the samples was obtained and calculated from the area under curves extrapolated automatically by the software (ChemStation, Germany). 


\section{Validation method}

It is the evaluation process used to ensure that the performance characteristics of an analytical procedure are to demonstrate that it is suitable for its intended purpose.

System Precision: It was conducted using five replicates of the caffiene standard solution with acceptance criteria of Relative Standard Deviation (RSD) $\leq 1 \%$ according to the International Conference on Harmonization of technical requirements for registration of pharmaceuticals for human use (ICH).

Linearity and range: Linearity was performed by preparing a minimum of five different concentrations of drug standard and defined by the squared correlation coefficient, which should be $0.99\left(\mathrm{r}^{2}\right)$ according to ICH.

Precision method: It was conducted using five replicates of tilmicosin standard solutions with acceptance criteria of RSD $\leq 1 \%$ according to $\mathrm{ICH}$.

Selectivity and specificity: Verification of selectivity was conducted by evaluating the spiked standard response following extraction from different chicken tissues. Regarding the acceptance criteria, there is no interference between the pure standard and peaks of any impurities or extracted solvents according to ICH.

Accuracy and recovery: The tissue samples of chickens were spiked by adding known quantities of tilmicosin. Those samples were analyzed against standard solutions of the corresponding concentrations. The method was accurate according to the calculated test results from the $\%$ recovery.

Limit of detection (LOD): It is the concentration which gives signal to noise ratio $3: 1$ according to $\mathrm{ICH}$.

Limit of quantification (LOQ): It is the concentration which gives signal to noise ratio 10:1 according to ICH.
Ruggedness: It was conducted by the analysis of the same samples under different conditions, such as different personnel, different times..etc. Acceptance criteria: pooled RSD is not more than $6 \%$ in every change item.

Robustness: It was determined by observing how an analytical procedure is a measure of its capacity to remain unaffected by small, but deliberate variations in method parameters and provides an indication of its reliability during normal usage. Acceptance criteria: pooled RSD is not more than $6 \%$ in every change item.

\section{Results}

\section{Method validation results}

The HPLC system was found precise because the RSD of five replicates of caffiene standard solution was $0.001 \%$. High correlation coefficient was obtained indicating linearity $\left(r^{2}=0.99606\right)$. The method for separating tilmicosin was precise as the RSD of seven replicates of tilmicosin standard solution was $0.498 \%$. There was no interference between the pure standard and peaks of any impurities or extracted solvents. The retention time (R.T.) of tilmicosin was $6.86 \mathrm{~min}$ (Figure 1A). The percentage recovery of tilmicosin spiked samples ranged from $97-99 \%$. The LOD for tilmicosin was $0.015 \mu \mathrm{g} / \mathrm{mL}$, while, LOQ was $0.045 \mu \mathrm{g} / \mathrm{mL}$. The pooled RSD for tilmicosin was $4 \%$.

\section{Standard curve preparation}

Tilmicosin standard concentrations of 0.05 , $0.1,0.2,0.5,1,2$ and $5 \mu \mathrm{g} / \mathrm{mL}$ and their corresponding peak responses were illustrated in Table (1) and Figure (1B). The calibration curve was calculated by linear regression equation method as $\mathrm{y}=590.419507 \mathrm{x}-10.3641$ where y symbol indicated the area under peak and $\mathrm{x}$ symbol indicated concentrations of tilmicosin. Linearity existed witin the range of 0.05 and $5 \mu \mathrm{g} / \mathrm{mL}$ with a correlation coefficient $r^{2}=0.99606$. 
Table 1: The concentrations of Tilmicosin standard $(\mu \mathrm{g} / \mathrm{mL})$ and their corresponding peak response

\begin{tabular}{cccc}
\hline RT $^{*}$ & Level & Amount $(\boldsymbol{\mu g} / \mathbf{m L})$ & Area under curve \\
\hline $\mathbf{6 . 8 6}$ & 1 & 0.050 & 39.3 \\
& 2 & 0.100 & 78.6 \\
& 3 & 0.200 & 134.2 \\
& 4 & 0.500 & 231.2 \\
& 5 & 1.000 & 680.1 \\
& 6 & 2.000 & 975.8 \\
& 7 & 5.000 & 3003.1 \\
\hline
\end{tabular}

*RT: Retention time

\section{Tissue residues}

Tilmicosin distribution in tissues was represented in Table (2) and Figure (1 C-E). The represented data emphasized a widespread distribution of the drug in tested tissues (liver, kidneys and muscles). The highest concentration of tilmicosin residues was detected in the liver $(3.84 \pm 0.35 \mu \mathrm{g} / \mathrm{gm})$ followed by kidneys $(2.28 \pm 0.13 \mu \mathrm{g} / \mathrm{gm})$ while the lowest concentration was detected in the muscles $(1.33 \pm 0.12 \mu \mathrm{g} / \mathrm{gm})$ at the first day after the last oral dosage. Tilmicosin remained within the detectable level till the $7^{\text {th }}$ day in most tested tissues but disappeared in muscles, while in liver; it remained till the $9^{\text {th }}$ day after treatment with the drug.

\section{Hematological and biochemical results}

Tilmicosin elicited significant decrease in most blood parameters (RBCs, Hb, PCV, lymphocytes, eosinophiles), while heterophiles and MCV showed significant increase. However, no significant change was recorded in WBCs, MCH, MCHC and monocytes. Values of all the tested cardiac enzymes (AST, LDH, CK-MB and Troponin I) were highly elevated (Tables 3 and 4).

Table 2: The concentrations of tilmicosin in tissues of sacrificed broilers at various intervals after treatment $(30 \mathrm{mg} / \mathrm{kg} \mathrm{BW}$ once daily for 3 consecutive days) $(\mathrm{n}=5)$

\begin{tabular}{lcccccc}
\hline Tissues & \multicolumn{7}{c}{ The concentration $(\boldsymbol{\mu g} / \mathbf{g m})$ mean \pm SE } \\
\cline { 2 - 7 } & $\mathbf{1}^{\text {st }}$ & $\mathbf{3}^{\text {rd }}$ & $\mathbf{5}^{\text {th }}$ & $\mathbf{7}^{\text {th }}$ & $\mathbf{9}^{\text {th }}$ & $\mathbf{1 4}^{\text {th }}$ \\
Liver & $3.84 \pm 0.35$ & $1.49 \pm 0.06$ & $1.06 \pm 0.04$ & $0.49 \pm 0.01$ & $0.28 \pm 0.05$ & ND $^{*}$ \\
Kidneys & $2.28 \pm 0.13$ & $1.39 \pm 0.06$ & $0.8 \pm 0.09$ & $0.07 \pm 0.01$ & ND & ND \\
Muscles & $1.33 \pm 0.12$ & $0.53 \pm 0.07$ & $0.17 \pm 0.03$ & ND & ND & ND \\
\hline
\end{tabular}

$* \mathrm{ND}=$ Not detected 


\section{Discussion}

Tilmicosin has been used for treatment of respiratory diseases in cattle, swine [14], rabbits [15] and rats [16]. The effect of tilmicosin $(30 \mathrm{mg} / \mathrm{kg} \mathrm{BW}$ once daily for 3 successive days) on the tissue residues following its oral administration was recorded. Following the oral administration, tilmicosin was detected in all tested tissues of normal healthy chickens following the last oral dose. Macrolides are generally hepatotoxic [17]. These results are consistent with Zhang et al. [13] who mentioned that the liver is the most concerned organ for tilmicosin residues in broiler chickens. Also, Fricke et al. [18] reported that the highest level of tilmicosin was found in liver followed by kidneys, lungs and muscles.

The maximum residue levels (MRLs) of tilmicosin in broiler chicken muscles, kidneys and liver are $0.075,0.25$, and 1.0 $\mu \mathrm{g} / \mathrm{g}$, respectively $[9,10]$. The reported withdrawal time is 10 days. In this study, tilmicosin could not be detected at the $9^{\text {th }}$ day after the last dose except in liver with a concentration of $0.28 \pm 0.05 \mu \mathrm{g} / \mathrm{g}$ which is approximately the quarter of the mentioned level. Our results were comparable with Stobba-Wiley et al. [19] who modified a validated method for quantitation of tilmicosin residues in swine, cattle, and sheep edible tissues, also chicken fat, skin, and muscles over a concentration range of $0.025-20 \mu \mathrm{g} / \mathrm{g}$. For chicken kidneys and liver, the method was developed over a range of $0.060-20 \mu \mathrm{g} / \mathrm{g}$, compared with our results; the lower concentrations ranged from $0.07-0.28 \mu \mathrm{g} / \mathrm{g}$ in muscles, kidneys and liver. According to Zhang et al. [13], a minimum withdrawal time of tilmicosin was 9 days which indicated that the residue levels in muscle, liver and kidney tissues were below MRL. This was partially in agreement with the results obtained during the current study.

In the present study, tilmicosin caused decrease in red blood cells (RBCs), hemoglobin $(\mathrm{Hb})$ and packed cell volume (PCV). In accordance, Yazar et al. [20] reported that tilmicosin caused significant decrease in RBCs counts in rabbits. However, our results disagreed with Xie et al. [21] and Yazar et al. [22] who mentioned that tilmicosin did not influence RBCs, hematocrit (HCT) value, mean corpuscular volume (MCV) and Hb. Also, our results were incomparable with Elsayed et al. [23] who reported that $\mathrm{Hb}$ and PCV concentration did not change with the administration of tilmicosin. In addition, the obtained results showed no significant change on MCH. Similarly, Xie et al. [21] found that tilmicosin had no significant change on the mean corpuscular hemoglobin $(\mathrm{MCH})$. 
Table 3: Effect of tilmicosin ( $30 \mathrm{mg} / \mathrm{kg} \mathrm{BW}$ once daily for 3 consecutive days) on hematological parameters of broiler chicken (mean \pm SE)

\begin{tabular}{|c|c|c|c|c|c|c|c|c|c|c|c|c|}
\hline $\bar{T}$ & G & $\begin{array}{c}\mathrm{Hb} \\
(\mathrm{g} \%)\end{array}$ & $\begin{array}{l}\text { RBCS } \\
\times 10^{6} / \mu \mathrm{l}\end{array}$ & $\begin{array}{c}\text { PCV } \\
\%\end{array}$ & $\begin{array}{c}\text { MCV } \\
\text { (fl) }\end{array}$ & MCH (Pg) & МСНC \% & WBCs & Eosinophile & Heterophiles & Lymphocyte & Monocytes \\
\hline $1 \mathrm{st}$ & G1 & $12.9 \pm 0.22$ & $3.1 \pm 0.03$ & $34.46 \pm 0.3$ & $111.22 \pm 1.12$ & $41.62 \pm 0.65$ & $37.42 \pm 0.42$ & $8.4 \pm 0.18$ & $0.69 \pm 0.01$ & $24.9 \pm 0.11$ & $72.18 \pm 0.05$ & $2.23 \pm 0.07$ \\
\hline day & G2 & $12.26 \pm 0.05$ & $3.36 \pm 0.02 * *$ & $34.18 \pm 0.04$ & $101.75 \pm 0.6 * *$ & $36.5 \pm 0.32 *$ & $35.5 \pm 0.32$ & $7.84 \pm 0.08$ & $0.66 \pm 0.01$ & $29.48 \pm 0.18 * *$ & $67.62 \pm 0.18 * *$ & $2.24 \pm 0.07$ \\
\hline 3 rd & G1 & $13.14 \pm 0.04$ & $2.96 \pm 0.05$ & $34.04 \pm 0.25$ & $115.15 \pm 1.22$ & $44.47 \pm 0.62$ & $38.61 \pm 0.28$ & $8.88 \pm 0.24$ & $0.65 \pm 0.01$ & $25.1 \pm 0.2$ & $71.9 \pm 0.21$ & $2.35 \pm 0.04$ \\
\hline day & G2 & $11.64 \pm 0.04 * *$ & $2.54 \pm 0.02 * *$ & $32.18 \pm 0.23 *$ & $126.7 \pm 0.4 * *$ & $45.85 \pm 0.47$ & $36.19 \pm 0.39 *$ & $8.48 \pm 0.15$ & $0.53 \pm 0.01 * *$ & $29.32 \pm 0.35 * *$ & $67.86 \pm 0.3 * *$ & $2.29 \pm 0.07$ \\
\hline 5 th & G1 & $13.04 \pm 0.07$ & $3.1 \pm 0.02$ & $34.08 \pm 0.19$ & $109.96 \pm 0.72$ & $42.08 \pm 0.39$ & $38.27 \pm 0.29$ & $8.88 \pm 0.13$ & $0.67 \pm 0.01$ & $25.32 \pm 0.34$ & $71.7 \pm 0.28$ & $2.31 \pm 0.04$ \\
\hline day & $\mathrm{G} 2$ & $10.48 \pm 0.05^{* *}$ & $2.32 \pm 0.03 * *$ & $27.82 \pm 0.24 * *$ & $119.95 \pm 0.6^{* *}$ & $45.22 \pm 0.57$ & $37.69 \pm 0.32$ & $8.16 \pm 0.14$ & $0.56 \pm 0.02 *$ & $31.5 \pm 0.51 * *$ & $65.54 \pm 0.5^{* *}$ & $2.4 \pm 0.04$ \\
\hline 7th & G1 & $13.04 \pm 0.09$ & $3.12 \pm 0.03$ & $34.22 \pm 0.26$ & $109.74 \pm 0.95$ & $41.81 \pm 0.26$ & $38.12 \pm 0.27$ & $8.6 \pm 0.23$ & $0.67 \pm 0.01$ & $25.02 \pm 0.14$ & $71.42 \pm 0.11$ & $2.29 \pm 0.02$ \\
\hline day & G2 & $9.36 \pm 0.07 * *$ & $2.08 \pm 0.03 * *$ & $24.68 \pm 0.26 * *$ & $118.68 \pm 0.33 * *$ & $45.05 \pm 0.58 *$ & $37.95 \pm 0.42$ & $7.5 \pm 0.15$ & $0.54 \pm 0.01 *$ & $31.3 \pm 0.44 * *$ & $65.76 \pm 0.46^{* *}$ & $2.4 \pm 0.06$ \\
\hline
\end{tabular}

T: time, G: group; G1: control; G2: tilmicosin; Hb: Hemoglobin; RBCs: red blood cells; PCV: packed cell volume; MCV: mean cor puscular volume; MCH: mean corpuscular hemoglobin; MCHC: mean corpuscular hemoglobin concentration; WBCs: white blood cells; WBCs, Eosinophile, Heterophiles, Lymphocyte and Monocytes were presented $\times 10^{3} / \mu \mathrm{l}$; *significant $\mathbf{P}<0.01$ and $* *$ significant $\mathbf{P}<0.001$.

Table 4: Effect of tilmicosin on cardiac enzymes of broiler chickens (Mean \pm S.E)

\begin{tabular}{|c|c|c|c|c|c|}
\hline Time & Group & $\begin{array}{l}\text { LDH } \\
\text { (U/L) }\end{array}$ & $\begin{array}{c}\text { CK-MB } \\
\text { (U/L) }\end{array}$ & $\begin{array}{c}\text { AST } \\
\text { (U/L) }\end{array}$ & $\begin{array}{c}\text { Troponin I } \\
(\mu \mathrm{g} / \mathrm{L})\end{array}$ \\
\hline \multirow[b]{2}{*}{$1^{\text {st }}$ day } & G1 & $67.4 \pm 0.66$ & $129 \pm 0.5$ & $15.52 \pm 0.11$ & $5.8 \pm 0.26$ \\
\hline & G2 & $87.2 \pm 0.61^{* * *}$ & $147.4 \pm 0.66^{* *}$ & $24.84 \pm 0.15^{* * *}$ & $79.2 \pm 0.61^{* * *}$ \\
\hline \multirow{2}{*}{$3^{\text {rd }}$ day } & G1 & $67.8 \pm 0.52$ & $127.2 \pm 0.57$ & $15.42 \pm 0.08$ & $8.2 \pm 0.41$ \\
\hline & G2 & $90.4 \pm 0.66^{* *}$ & $205.12 \pm 0.5^{* * *}$ & $27 \pm 0.12^{* *}$ & $87.6 \pm 0.53^{* *}$ \\
\hline \multirow{2}{*}{$5^{\text {th }}$ day } & G1 & $63 \pm 0.67$ & $128.4 \pm 0.36$ & $15.36 \pm 0.09$ & $9 \pm 0.39$ \\
\hline & $\mathrm{G} 2$ & $99.4 \pm 0.36^{* *}$ & $227.4 \pm 0.6^{* *}$ & $28.42 \pm 0.12^{* *}$ & $92.8 \pm 0.61^{* *}$ \\
\hline
\end{tabular}

G: group; G1: control; G2: tilmicosin; LDH: Lactate dehydrogenase enzyme; CK-MB: Creatine Kinase MB; AST: Aspartate Aminotransferase enzyme; *significant $\mathbf{P}<0.01$ and $* *$ significant $\mathbf{P}<0.001$. 
In the current study, there was no significant change in white blood cells (WBCs) count and monocytes on the $1^{\text {st }}, 3^{\text {rd }}, 5^{\text {th }}$ and $7^{\text {th }}$ days. The effect of tilmicosin on leukocytes is controversial. Xie et al. [21] confirmed that tilmicosin did not show any significant change in WBCs and monocytes. However, Yazar et al. [20] reported that tilmicosin caused statistically significant decrease in WBCs of rabbits and chicken. Also, our findings revealed a highly significant decrease in lymphocytes and esinophiles count. On the other hand, heterophiles count showed a highly significant increase. The previous results were incompatible with Xie et al. [21] who reported that tilmicosin did not change neutrophils, lymphocytes, eosinophils and basophils.

Measurement of the cardiac enzymes (AST, LDH and CK-MB) has been used since long time to detect cardiac and skeletal muscle injury, but these three biomarkers lack sensitivity and specificity [24,25]. Although increased CK-MB activity may be responsible for the myocyte damage, its elevation alone does not necessarily indicate the myocyte damage [26]. Therefore, troponin I was measured and in general, increased CKMB activity was associated with increased troponin I level [27]. It is accepted that troponin I may be a more sensitive marker than CK-MB in myocyte damage [28-30]. In this study, tilmicosin illustrated marked increase in all cardiac enzymes (LDH, CKMB, AST and troponin I) on $1^{\text {st }}, 3^{\text {rd }}$ and $5^{\text {th }}$ days post treatment. These results were supported by Yazar et al. [23] who mentioned that tilmicosin caused a significant increase in cardiac creatine kinase activity. Also, Ibrahim and AbdelDaim [31] reported that tilmicosin intoxication increased serum cardiac injury biomarkers LDH, $\mathrm{CK}$ and CK-MB. Moreover, Elazab et al. [32] stated that biochemical results demonstrated marked increase in serum aspartate transaminase (AST), lactate dehydrogenase (LDH), creatinekinase (CK) activities and cardiac troponin $\mathrm{T}$ (cTnT) concentrations in tilmicosin-treated rats indicating severe cardiotoxicity. However, our results were dissimilar to those previously reported by Jordan [33] who recorded non-significant changes in serum creatinine level, AST and ALT in cattle treated with tilmicosin. Also, with Altunok et al. [34] who reported that tilmicosin has no negative effects of on biochemical variables of rabbits. The difference may be due to species and dose difference. 


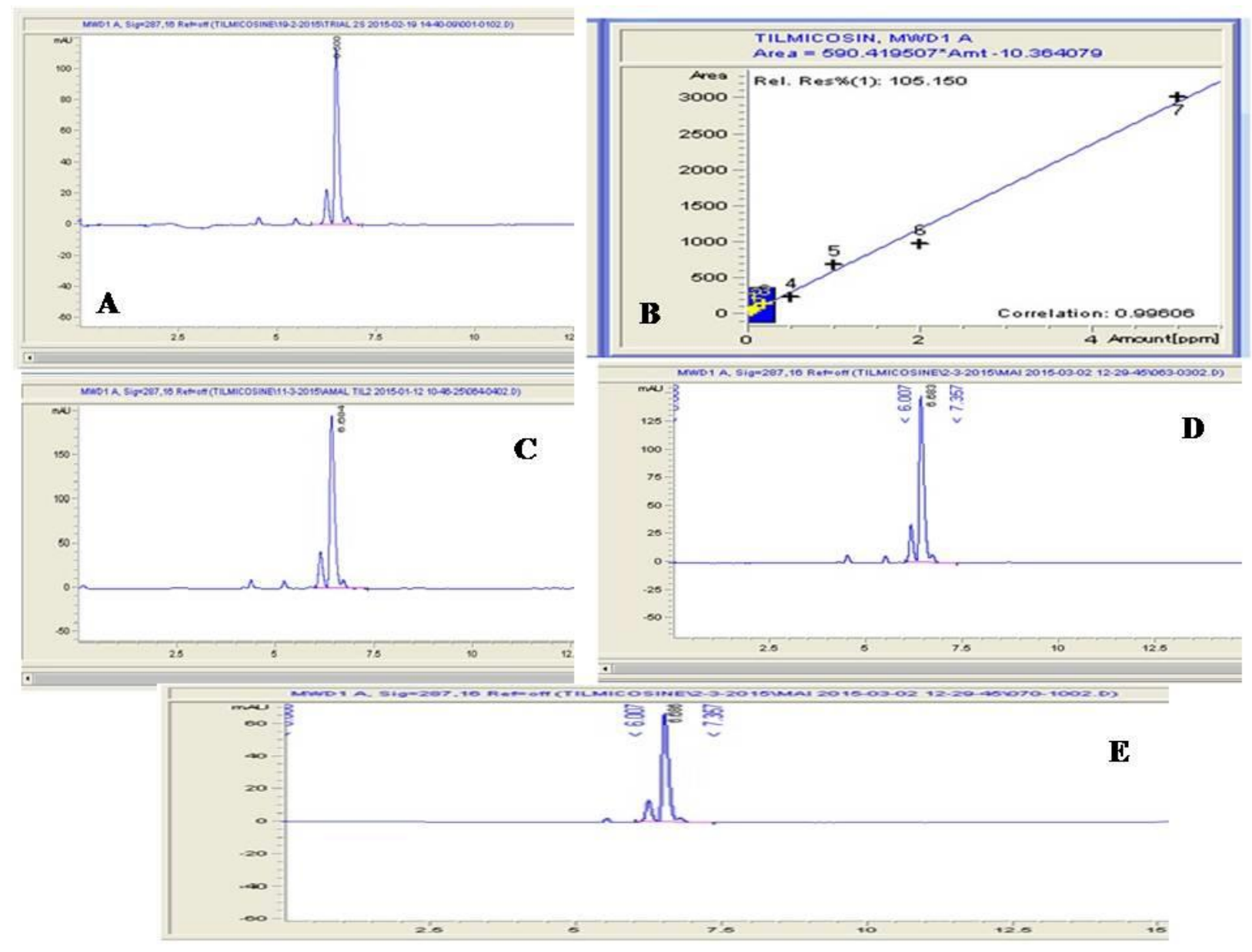

Figure 1: A: Chromatograms of tilmicosin standard $(2 \mu \mathrm{g} / \mathrm{mL})$, B: Standard curve of tilmicosin, Chromatograms of tilmicosin extract of broiler liver (C), kidney (D) and muscle (E) at $1^{\text {st }}$ day following last oral dose.

\section{Conclusion}

The present study clearly demonstrated that liver is the concerned tissue for tilmicosin residues in broiler till the $9^{\text {th }}$ day post treatment. Tilmicosin elicited significant decrease in most of blood parameters. In addition, tilmicosin induced elevation in cardiac markers.

\section{Conflict of interest}

None of the authors have any conflict of interest to declare.

\section{Acknowledgment}

I find it difficult to express in words my feeling and gratitude towards staff of Residue Analysis Unit, Animal Health Research Institute, Dokki, Giza for help and cooperation in practical work.

\section{References}

[1] Ose, E.E. (1987): In vitro antibacterial properties EL-870, a new semisynthetic macrolide antibiotic. J Antibiot, 40 (2): 190-194.

[2] Prescott, J.F. (2000): Macrolides and pleuromyilins. Antimicrobial Therapy in Veterinary Medicine, $3^{\text {rd }}$ edn. (Iowa State University Press, Ames, USA), pp:229262.

[3] Jordan, F.T.; Forrester, C.A.; Hodge, A. and Reeve- Johnson, L.G. (1999): The comparison of an aqueous preparation of tilmicosin with tylosin in the treatment of Mycoplasma gallisepticum infection of turkey poults. Avian Dis, 43 (3): 521-525.

[4] Abu-Basha, E.A.; Idkaidek, N.M. and AlShunnaq, A.F. (2007): Pharmacokinetics of 
tilmicosin (Provitil powder and Pulmotil liquid AC) oral formulations in chickens. Vet Res Commun, 31 (4): 477-485.

[5] Jordan, W.H.; Byrd, R.A.; Cochrane, R.L.; Hanasono, G.K.; Hoyt, J.A., Main, B.W., Meyerhoff, R.D., Sarazan, R.D. (1993): A review of the toxicology of the antibiotic MICOTIL 300. Vet Hum Toxicol, 35 (2): $151-158$

[6] Main, B.W.; Means, J.R.; Rinkema, L.E.; Smith, W.C. and Sarazan, R.D. (1996): Cardiovascular effects of the macrolide antibiotic tilmicosin, administered alone and in combination with propranolol or dobutamine, in conscious unrestrained dogs. J Vet Pharmacol Ther, 19 (3): 225232.

[7] Papich, M.G. and Riviere, J.E. (2001): Chloramphenicol and derivatives, macrolides, lincosamides, and miscellaneous antimicrobials, in Veterinary Pharmacology and Therapeutics, H.R. Adams, (Ed.). Iowa State University Press, Ames, Iowa, USA, $8^{\text {th }}$ edition, pp. 868-897.

[8] Sande, M.A. and Mandell, G.L. (1985): Antimicrobial agents, tetracycline, chloramphenicol, erythromycin and miscellaneous antibacterial agents. In: The pharmacological basis of therapeutics. Goodman Gilman A.L.S; Rall; T.W.; Murad, F. (Eds.). Macnillan puplishing company New York, pp: 1110-1118.

[9] EMA (1996): European Medicines Agency, The European Agency for the Evaluation of Medicinal Products, Veterinary Medicines Evaluation Unit, Committee for veterinary medicinal products. Tilmicosin, Summary Report [DB/OL].

[10] Agricultural Department of P. R. China (2002): $235^{\text {th }}$ Bulletin, Agricultural Department of P. R. China: People's Republic of China.

[11] Stephen, F. and Sundlof, D.V.M. (1994): Human risks associated with drug residues in animal derived food. J Agromedicine, 1(2): 5-20.
[12] Juhel-Gaugain, M.; Anger, B. and Laurentie, M. (1999): Multiresidue chromatographic method for the determination of macrolide residues in muscle by high-performance liquid chromatography with UV detection. J AOAC int, 82(5): 1046-1053.

[13] Zhang, Y.; Jiang, H.; Jin, X.; Shen, Z.; Shen, J.; Fu, C. and Guo, J. (2004): Residue depletion of tilmicosin in chicken tissues. J Agric Food chem, 52 (9): 26022605.

[14]Moran, J.W; Turner, J.M.; Coleman, M.R.J (1997): Determination of tilmicosin in bovine and porcine sera by liquid chromatography. J AOAC Int, 80: 11831189.

[15] Mckay, S.G.; Morck, D.W.; Merrill, J.K.;Olson, M.E.; Chan, S.C.; and Pap, K.M. (1996): Use of tilmicosin for treatment of pasteurellosis in rabbit. Am $\mathrm{J}$ Vet Res, 57(8):1180-1184

[16] Modric, S.; Webb, A.I. and Davidson, M. (1999): Effect of respiratory tract disease on pharmacokinetics of tilmicosin in rats. Lab Anim Sci,49 (3): 248-253.

[17] Barragry, T.B. (1994): Aminoglycosides, macrolides, and lincosamides. In: Veterinary Drug Therapy. Williams \& Wilkins, Philadelphia, USA, pp: 241-263.

[18] Fricke, J.A.; Clark, C.R.; Boison, J.O.M.; Chirino-Trejo, T.E.; Inglis, S. and Dowling, P.M. (2008): Pharmacokinetics and tissue depletion of tilmicosin in turkeys. J Vet Pharmacol Ther, 31(6): 591594.

[19] Stobba-Wiley, C.M.; Chang, J.P.; Elsbury, D.T.; Moran, J.W. and Readnour, R.S. (2000): Determination of tilmicosin residues in chicken, cattle, swine and sheep tissues by liquid chromatography. J. AOAC Int.; 83(4):837-846.

[20] Yazar, E.; Altunok, V.; Elmas, M.; Tras, B.; Bas, A.L. and Ozdemir, V. (2001): Effect of tilmicosin on cardiac muscle and serum creatine kinase activities and serum 
total protein level in healthy male Balb/C mice. Revue Med Vet, 152 (12): 881-883.

[21] Xie, S.; Wang, F.; Wang, Y.; Zhu, L.; Dong, Z.; Wang, X.; Li, X. and Zhou, W.Z. (2011): Acute toxicity study of tilmicosin-loaded hydrogenated castor oilsolid lipid nanoparticles. Part Fibre Toxicol, 8 (33):1-10

[22] Yazar, E.; Oztekin, E.; Sivrikaya, A.; Col, R.; Elmas, M. and Bas, A. L. (2004): Effects of Different Doses of Tilmicosin on Malondialdehyde and Glutathione Concentrations in Mice. Acta Vet Brno,73: 69-72.

[23] Elsayed, M.; Elkomy, A.; Aboubakr, M. and Morad, M. (2014): Tissue residues, Hematological and Biochemical Effects of Tilmicosin in Broiler Chicken. Vet Med Int, 2014:502872. Doi: $10.1155 / 2014 / 502872$.

[24] Chan, D. and Ng, L.L. (2010): Biomarkers in acute myocardial infarction. BMC Med, 8: 34. Doi: 10.1186/1741-7015-8-34.

[25] Kaur, H; Gupta, S.; Verma, M.; Singh, K. and Singh, J. (2013): Clinical significance and effectiveness of various serum biomarkers in diagnosis of myocardial infarction. Int J Bioassays, 2(8): 10731078 .

[26] Moss, D.W. and Henderson, A.R. (1994): Enzymes. In: Clinical chemistry, Burtis, C.A. and Ashwood., E. R. $2^{\text {nd }}$ edition, WB Sounders Company, Phidelphia, USA, pp: 735-888.

[27] Ooi, D.S.; Isotalo, P.A. and Veinot, J.P. (2000): Correlation of antemortem serum creatine kinase, creatine kinase-MB, troponin $\mathrm{I}$ and troponin $\mathrm{t}$ with cardiac pathology. Clin Chem, 46 (3): 338-344.

[28] Horton, J.W.; Garcia, N.M.; White, D.J. and Keffer, J. (1995): Postburn cardiac contractile function and biochemical markers of postburn injury. J Am Coll Surg, 181 (4): 289-298.

[29] Smith, S.C.; Ladenson, J.H.; Mason, J.W. and Jaffe, S.J. (1997): Elevations of cardiac troponin I associated with myocarditis. Experimental and Clinical Correlates Cir, 95 (1): 163-168.

[30] Chen, Y.N.; Wei, J.R.; Zeng, L.J. and Wu, M.Y. (1999): Monitoringof cardiac troponin $\mathrm{I}$ in patients with acute heart failure. Ann Clin Biochem, 36 (Pt 4): 433437.

[31] Ibrahim, A.E. and Abdel-Daim, M.M. (2015): Modulating effects of spirulina platensis against tilmicosin-induced cardiotoxicity in mice. Cell J, 17(1): 137144.

[32] Elazab, M.F.A..; Gomaa, G.M. and Abdo, W. (2014): Protective effect of S-methyl cysteine against tilmicosin-induced cardiotoxicity in rats. Pak Vet J, 34(3): 337-340.

[33] Jordan, W.H. (1992): The drug tolerance study of tilmicosin administered subcutaneously to Beef Cattle. Am J vet,75(6):1159-1165.

[34] Altunok, V.; Yazar, E.; Elmas, M.; Tras, B.; Bas, A. L. and Col, R. (2002): Investigation of haematological and biochemical side effects of tilmicosin in healthy New Zealand Rabbits. J Vet Med. B, 49 (2), 68-70. 


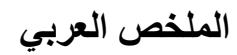

$$
\begin{aligned}
& \text { تحديد البقايا الدوائية للتلميكوزين بواسطة جهاز التحليل الكروماتوجرافي العالي الكفاءة وتأثيره علي اتزيمات القلب } \\
& \text { ومكونات الام فى دجاج التسمين }
\end{aligned}
$$

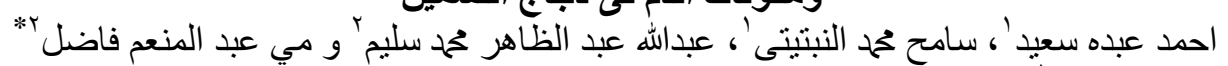

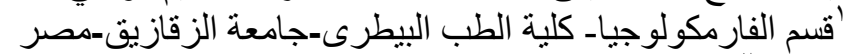

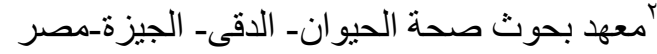

استهدفت هذه الدر اسة قياس بقايا التلميكوزين فى أنسجة دجاج التسمين المختلفة (الكبد، الكلى و العضلاتلات) بعد اعطاء

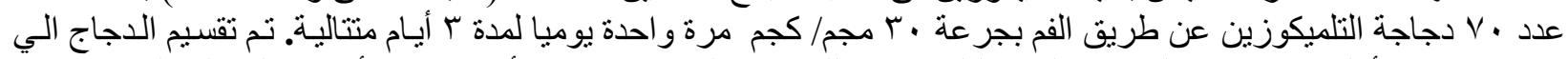

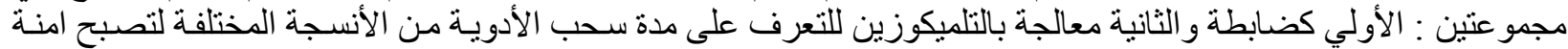

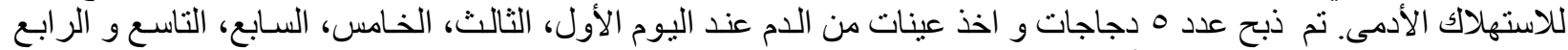

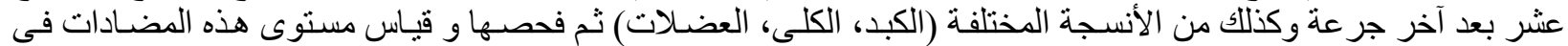

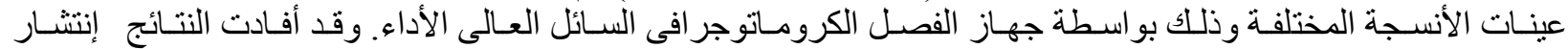

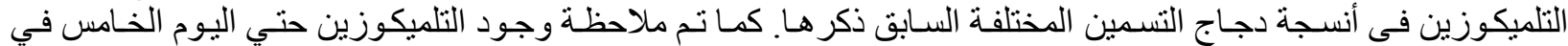

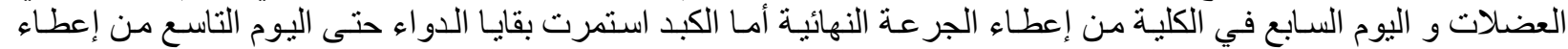

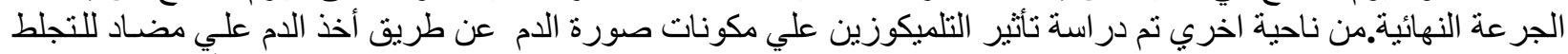

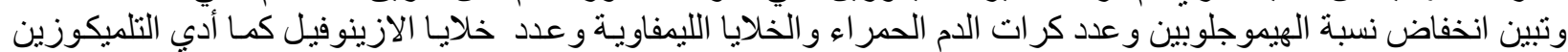

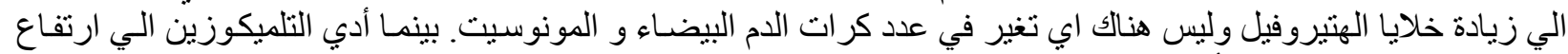

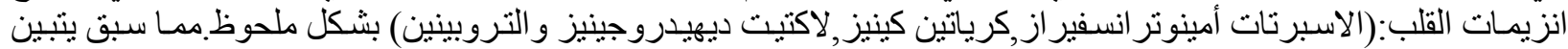
مدي خطورة بقايا التلميكوزين في أنسجة دجاج التسمين علي صحة الانسان. 